Research article

\title{
GASTROINTESTINAL NEMATODE INFECTIONS IN ANTELOPES FROM MOROCCO: A COPROLOGICAL SURVEY
}

\author{
SAIDI Aissa ${ }^{1,2 *}$, MIMOUNI Rachida ${ }^{2}$, HAMADI Fatima ${ }^{2}$, OUBROU Widade ${ }^{3}$ \\ ${ }^{1}$ Regional Laboratory of Research (ONSSA), Agadir, Morocco; ${ }^{2}$ Department of Biology, College of \\ Science, Ibn Zohr University, Agadir, Morocco; ${ }^{3}$ Souss-Massa National Park, Agadir, Morocco
}

(Received 19 April 2020, Accepted 08 February 2021)

This study examined the gastrointestinal parasitological status of three endangered Sub-Saharan antelope species (Addax nasomaculatus, Oryx dammah, Gazella dorcas) hosted at Souss-Massa National Park in Morocco. A total of 254 faecal samples (80 samples from the addax population, 81 from the oryx population and 93 from the dorcas population) were analysed to determine the prevalence and the intensity of the parasites in host faeces (expressed as the mean EPG: egg per gram), using microscopic methods (Flotation and McMaster) and the molecular identification of parasites using PCR and sequencing of the second internal transcribed spacer region of the rDNA (ITS-2).

The prevalence results in the addax, oryx and dorcas gazelle were $43.7 \%, 2.4 \%$, and $61.3 \%$, respectively, for Nematodirus spp.; $21.2 \%, 12.3 \%$, and $16.13 \%$, respectively, for Trichuris spp.; and $36.2 \%, 39.5 \%$, and $53.7 \%$, respectively, for other, undistinguished strongylids.

The means of EPG values for parasites in addax, oryx and dorcas gazelle were 8.9, 2.4, and 61.3, respectively, for Nematodirus spp.; 4.3, 2.4, and 4.8, respectively, for Trichuris spp.; and 18.1, 16.6, and 50.1, respectively, for other undistinguished strongylids. Sequencing of the ITS-2 rDNA region of the isolated parasites allowed the identification of Camelostrongylus mentulatus and Nematodirus spathiger in these three antelope species. We can conclude that the studied antelopes are infected at tolerating levels with the first record of Camelostrongylus mentulatus and Nematodirus spathiger in those antelopes in Morocco.

Keywords: African threatened antelopes; Camelostrongylus mentulatus; gastrointestinal nematodes; ITS-2 rDNA; Morocco; Nematodirus spathiger.

\section{INTRODUCTION}

Morocco is one of the Mediterranean countries with the highest diversity of wild mammals [1]. The current study examined three threatened species of Sahelo-Saharan

*Corresponding author: e-mail: aissasaidivet@gmail.com 
antelopes: Addax nasomacculatus (De Blainville, 1816), Oryx dammah (Cretzschmar, 1826) and Gazella dorcas (Linnaeus, 1788). Before their disappearance from nature, these species inhabited the desert areas of southern Morocco [2]. The three antelopes appear on the red list of threatened species of the International Union for Conservation of Nature (IUCN). According to the list, addax is categorized as "critically endangered", oryx as "extinct in the wild" and dorcas gazelle as "vulnerable" [3-5]. The antelopes were reintroduced successfully two decades ago to Souss-Massa National Park (Agadir, Morocco); addax and oryx were brought from European zoos and dorcas gazelle from the remaining native population [6]. For the purpose of conserving its fauna, Morocco was among the African countries that ratified the agreement for the conservation of sub-Saharan antelopes in the Agadir declaration [7]. In this context, several parks and reserves have been set up to accommodate various endangered species throughout the country. However, animals kept in such conditions of semi-captivity require the control of health management, especially in relation to infectious and parasitic diseases $[8,9]$.

As grazing ruminants, antelopes are exposed to different internal parasitic infections namely coccidian [10], pulmonary nematodes [11], and particularly gastrointestinal nematodes [12,13]. In nature, parasites and hosts maintain a balanced relationship. However, this equilibrium may deteriorate when animals are subjected to conditions such as translocation, sequestration, overcrowding or climate change [14]. Intense parasitism can have pronounced impacts on wildlife host populations; it may affect their fecundity, their survival, their growth or even their behavior [15-17].

This survey aimed to explore the gastrointestinal parasitic status of the studied animals to further, develop a dashboard that will serve the park's health management programs. Many tools may be used to assess the parasite burden in wildlife, by necropsy or by examining some biochemical and serological parameters [18]. However, since the studied antelopes are threatened species, it was more appropriate to use noninvasive methods based on coprological techniques. For that, we first measured the prevalence and the intensity of parasites in the feces of the three species of antelopes. Second, we proceeded to the molecular identification of isolated nematodes.

\section{MATERIALS AND METHODS}

\section{Area of study}

Created in 1991, the National Souss-Massa Park (SMNP) covers an area of 33800 ha, along the Atlantic coast, $70 \mathrm{~km}$ long and $7 \mathrm{~km}$ wide. It is located between the cities of Agadir, to the North, and Tiznit, to the South (Figure 1). It is considered a wetland, irrigated with two seasonal rivers, Souss and Massa, whose deltas are included in the park area. It has sandy soil and a savannah-like ecosystem, containing diversified endemic Mediterranean and Saharan flora (e.g., Argania spinosa and Atriplex halimus...). In addition to the three antelopes, the park supports a diverse fauna with a large variety of endemic reptiles, birds, small mammals and other endangered species, such as the bald ibis (Geronticus eremita) and the red-necked ostrich (Struthio camelus camelus). 


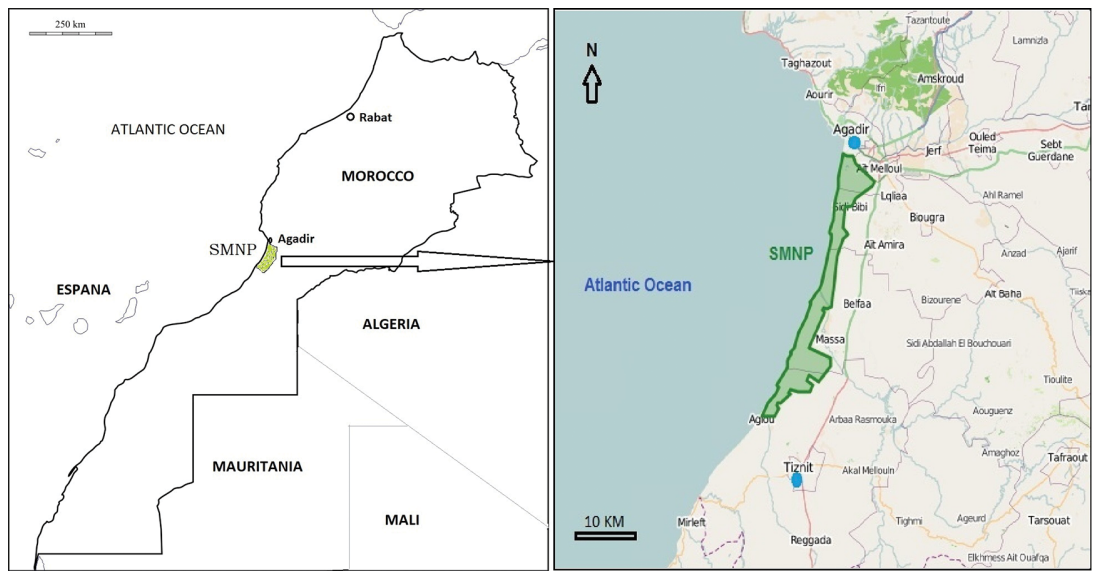

Figure 1. Map showing the localization of the park within Morocco (left) and its geographic extent (right)

\section{Animals and sampling procedure}

To avoid conflict and hybridization-related problems between oryx and addax, the animals are hosted in two separate geographical spots within the SMNP. The addax is housed in the Rokein reserve with a part of dorcas gazelles, while the oryx is housed in the Arrouais reserve with the other part of dorcas gazelles. The current population sizes of antelopes are estimated at 440 individuals for addax, 250 individuals for oryx, and 850 individuals for dorcas gazelle.

According to their availability, morning fresh individual fecal pellets of herds were randomly collected from the ground (regardless of the age and sex of the animals). The fecal pellets of each species are easily distinguishable by their size; pellets of gazelles are smaller than those of oryx and addax. A total of 254 samples were collected from January to July 2015 (80 samples from the addax population, 81 from the oryx population and 93 from dorcas gazelle population). All samples were labeled, transported immediately to the laboratory, and kept in the refrigerator at $4^{\circ} \mathrm{C}$ until used (no more than 2 weeks).

\section{Recovery and eggs counting}

Nematode eggs were detected by simple test tube flotation and counted by the McMaster method to measure the fecal eggs per gram (EPG), as in domestic ruminants [19]. Sheather's sugar solution (454 g of granulated sugar, $355 \mathrm{ml}$ of tap water and 6 $\mathrm{ml}$ of formaldehyde), with a specific gravity of 1.27 was used in this study [20]. Briefly, the fecal suspension was prepared by adding $4 \mathrm{~g}$ of feces to $56 \mathrm{ml}$ of flotation solution and sieved with a tea strainer, and then microscope slide examinations were done at 100-400 x magnifications for both the tube flotation and McMaster method. 


\section{Larvae isolation for DNA extraction}

For L3 stage larvae culture, crushed and moistened fecal pellets were deposited into glass Petri dishes and incubated at $27^{\circ} \mathrm{C}$ for 7 days for the majority of Trichostrongylidae nematodes, and after 14 days for Nematodirus spp. following a laboratory guide for domestic ruminants [21], then the L3 larvae were collected by the Baermann funnel method [22]. A volume of $20 \mu \mathrm{l}$ of L3 larval suspension was examined on a glass slide under an inverted microscope at $250 \mathrm{x}$ magnification. Next, one unique larva was isolated by aspiration with a P10 micropipette, washed twice in water and then conserved in $10 \mu \mathrm{l}$ of water in a $0.5 \mathrm{ml}$ microtube at $-20^{\circ} \mathrm{C}$.

\section{DNA Extraction Procedure}

DNA extraction was done following the tissue protocol of the QIAGEN QIAamp DNA Mini Kit (QIAGEN Lake Constance GmbH, Germany) with a slight modification in the tissue digestion step. A $0.5 \mathrm{ml}$ microtube containing a larva or an egg was thawed, and then $180 \mu \mathrm{l}$ of buffer ATL and $20 \mu \mathrm{l}$ of Proteinase K were added. The microtube was vortexed and centrifuged for a few seconds, and then the contents were transferred to a $2 \mathrm{ml}$ microtube containing $0.5 \mathrm{~mm}$ Zirconia/Silica beads (BioSpec ${ }^{\circledR}$, BioSpec Products, Inc., USA) and incubated for $1 \mathrm{~h}$ at $56^{\circ} \mathrm{C}$ and 900 $\mathrm{rpm}$ in a microtube thermal shaker (CAT®-H26). Then we collected $200 \mu$ l volume of the digestion product and followed the next steps of the QIAGEN protocol.

\section{PCR amplification conditions}

PCR assays targeted the internal transcribed spacer (ITS-2) regions of the ribosomal DNA of nematodes. For that purpose, universal primers were used: the forward primer NC1: 5'ACGTCTGGT'TCAGGGT'TGT'T and the reverse primer NC2: 5'T'TAGT'TC'T'T'T'TCCTCC GC'T-3', described previously [23].

PCR amplification was performed using the AgPath-ID ${ }^{\text {TM }}$ kit (Ambion ${ }^{\circledR}$-Applied Biosystems) in a total volume of $50 \mu \mathrm{l}$ per reaction, which contained $10 \mu \mathrm{l}$ of DNA extract, $2 \mu \mathrm{l}$ of each $10 \mu \mathrm{M}$ primer, $2 \mu \mathrm{l}$ of 25X RT-PCR Enzyme Mix, $25 \mu \mathrm{l}$ of 2X RTPCR Buffer and $9 \mu$ l of water. PCR was carried out in a Bio-Rad iCycler ${ }^{\circledR}$ Thermal cycler with an initial denaturation at $94^{\circ} \mathrm{C}$ for 10 min followed by 40 cycles, $45 \mathrm{~s}$ each, of denaturation at $94^{\circ} \mathrm{C}$, annealing at $55^{\circ} \mathrm{C}$ and extension at $72^{\circ} \mathrm{C}$, with a final extension at $72^{\circ} \mathrm{C}$ for $5 \mathrm{~min}$. PCR amplicons were visualized by electrophoresis in a $2 \%$ agarose gel; positive samples were identified by the presence of a band of $\sim 300 \mathrm{bp}$.

\section{DNA sequencing and phylogenetic analysis}

Positive PCR products were submitted to a sequencing service provider (BIO BASIC ${ }^{\text {, }}$ Markham ON, Canada) for purification and Sanger dideoxy sequencing using the same primers for PCR. Electropherograms were examined by Sequence Scanner Software v1.0 (Applied Biosystems). The GenBank database was searched for sequences that 
matched the sequencing results using the BLAST algorithm hosted by the national center for biotechnology information (NCBI) network server [24]. Sequences alignments were performed using BioEdit v7.2.6 software, and phylogenic analysis by MEGA v7.0 software [25]. Phylogenic trees were constructed by the neighborjoining method after 1000 bootstraps [26]. Seventeen sequences were deposited in the GenBank database: [MH047854-MH047855], [MH047838-MH047839], [MH047843MH047844], [MH047850], [MH047830-MH047831], [MH047835], [MH047846$\mathrm{MH} 047849]$, and [MH047840-MH047842].

\section{Statistical analysis of data}

Coprological data are presented as percentages for prevalence and means \pm standard deviation for parasite intensity. The differences in prevalence were analyzed using the $\chi^{2}$ test (95\% confidence interval), and parasite intensity values among the three populations of antelopes were compared with one-way analysis of variance (ANOVA) and the Newman-Keuls multiple comparison test, with P-values of $<0.05$ indicating significance (GraphPad PRISM ${ }^{\circledR}$ v5.00 software, USA).

\section{RESULTS}

\section{Prevalence and intensity}

The coprological examination revealed various forms of gastrointestinal nematode eggs of different nematode genera: Nematodirus spp., Trichuris spp. and other undistinguishable strongylids. The prevalence and the intensity values varied according to the parasite and its host (Table 1).

Table 1. Prevalence and intensity values (EPG) for parasites recovered from fecal samples of antelopes.

\begin{tabular}{lcccccc}
\hline & \multicolumn{2}{c}{ Strongylids } & \multicolumn{2}{c}{ Nematodirus spp. } & \multicolumn{2}{c}{ Trichuris spp. } \\
\cline { 2 - 7 } & $\begin{array}{c}\text { Prevalence } \\
\mathbf{\%}\end{array}$ & $\begin{array}{c}\text { Intensity } \\
\text { mean } \pm \text { SD }\end{array}$ & $\begin{array}{c}\text { Prevalence } \\
\mathbf{\%}\end{array}$ & $\begin{array}{c}\text { Intensity } \\
\text { mean } \pm \text { SD }\end{array}$ & $\begin{array}{c}\text { Prevalence } \\
\mathbf{\%}\end{array}$ & $\begin{array}{c}\text { Intensity } \\
\text { mean } \pm \text { SD }\end{array}$ \\
\hline Addax nasomaculatus & $36.2(29 / 80)$ & $18.1 \pm 34.9$ & $43.7(35 / 80)$ & $8.9 \pm 25.1$ & $21.2(17 / 80)$ & $4.3 \pm 14.2$ \\
Oryx dammah & $39.5(32 / 81)$ & $16.6 \pm 32.6$ & $2.4(2 / 81)$ & $1.8 \pm 16.7$ & $12.3(10 / 81)$ & $2.4 \pm 10.9$ \\
Gazella dorcas & $53.7(50 / 93)$ & $50.1 \pm 143.8$ & $61.3(57 / 93)$ & $12.3 \pm 33.5$ & $16.13(15 / 93)$ & $4.8 \pm 16.5$ \\
\hline
\end{tabular}

For prevalence rates, we noticed that there were no significant differences across the three antelope populations in Trichuris spp. or strongylid nematodes. In contrast, the Nematodirus spp. prevalence rate in oryx was significantly lower than in addax and dorcas gazelle.

Data analysis of intensity means revealed no significant differences in Trichuris spp. among the three antelopes, but the Nematodirus spp. intensity mean was significantly 
lower in oryx than in gazelles. We noticed also that the strongylids intensity mean was significantly higher in dorcas gazelle than in addax and oryx.

\section{Molecular identification and phylogenetic analyses}

The sequences alignment results allowed the identification of many isolates: Camelostrongylus mentulatus and Nematodirus spathiger in the three antelope species and other Trichostrongylus spp. in dorcas gazelle and oryx.

All six C. mentulatus sequences isolated from the three antelope species showed a percentage of identity higher or equal to $98 \%$ compared to the GenBank reference sequence [KY930444], with a fixed three-nucleotide deletion (152_154delGTA) and a nucleotide substitution $(246 \mathrm{~T}>\mathrm{A})$; in addition, the three sequences isolated from $G$. dorcas [MH047837, MH047838, MH047839] showed a fixed nucleotide substitution $(213 \mathrm{~A}>\mathrm{G})$. The phylogenetic tree and alignment results for these sequences are shown in Figures 2 and 3.

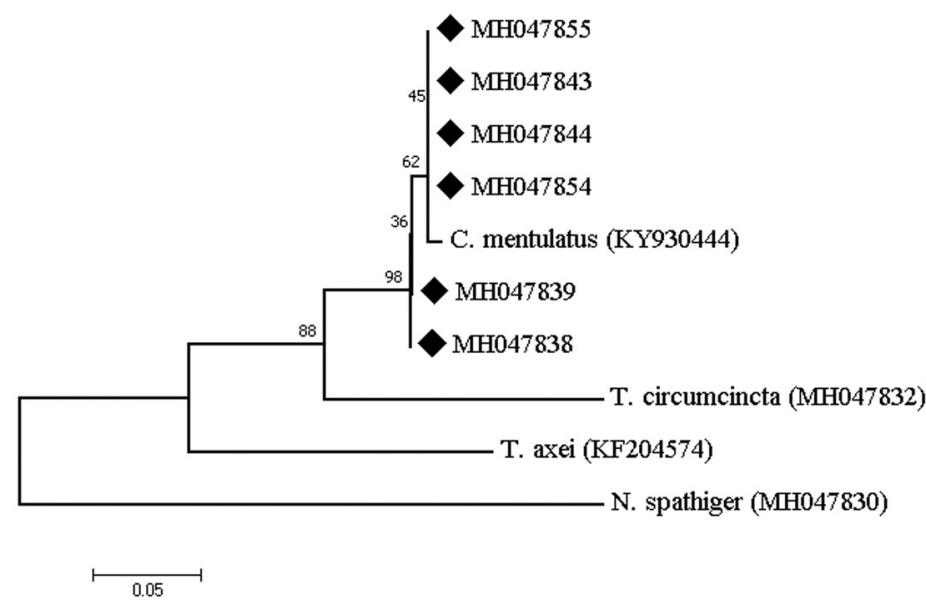

Figure 2. The phylogenetic relationships of Camelostrongylus mentulatus based on ITS-2 sequences of the rDNA, using the Neighbor-Joining method with the Tamura 3-parameter method. The percentages of replicate trees in the bootstrap test (1000 replicates) are shown next to the branches. The tree is drawn to scale, with branch lengths in the same units as those of the evolutionary distances used to infer the phylogenetic tree. The analysis involved 10 nucleotide sequences ( 6 from antelopes, and 4 from Genbank). Evolutionary analyses were conducted in MEGA7.

For N. spathiger, the four sequences isolated from antelopes showed a percentage of identity higher than $99 \%$ when compared to the reference sequence isolated in G. dorcas from Tunisia [KY930420]. Similarities between isolates and the reference sequence are represented as a phylogenetic tree in Figure 4. 


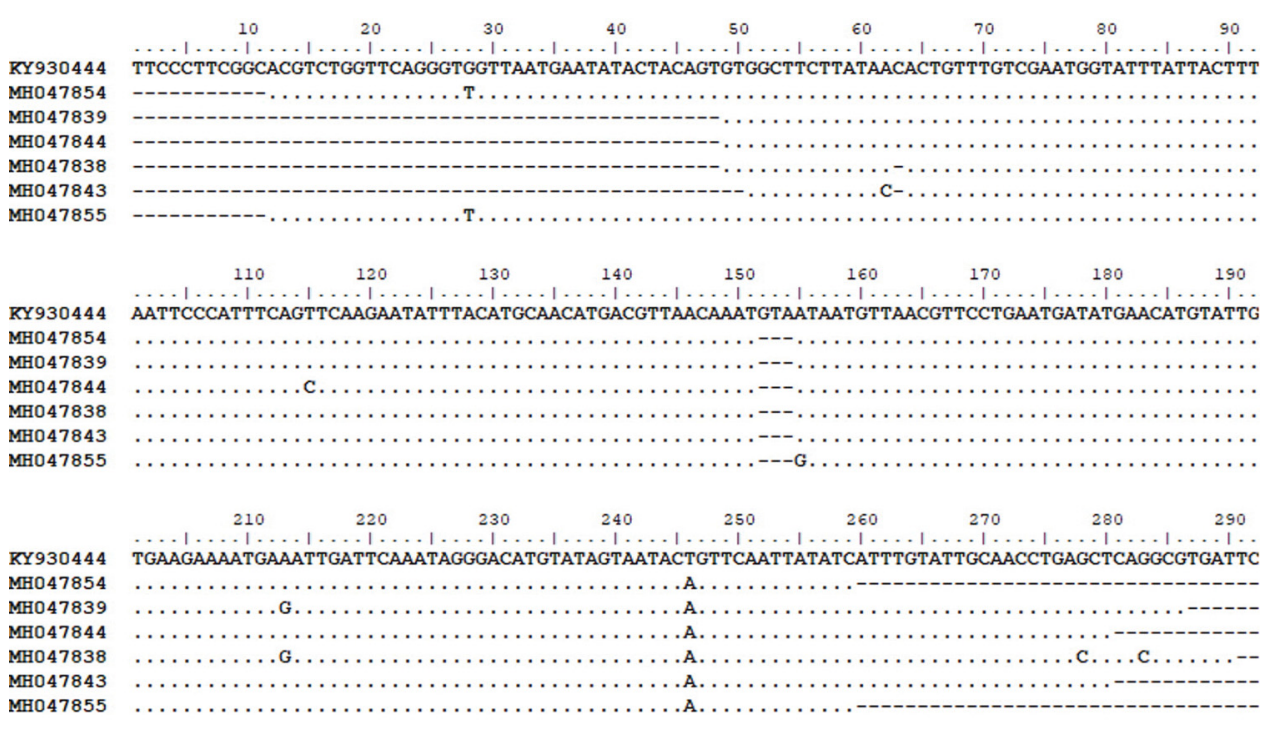

Figure 3. Alignment, done in BioEdit v7.2.6, showing substitutions and deletions, between Moroccan antelope sequences of Camelostrongylus mentulatus (MH047838, MH047839, MH047843, MH047844, MH047854, MH047855) and the Tunisian Addax sequence (KY930444). Dots, residues that match the consensus exactly.

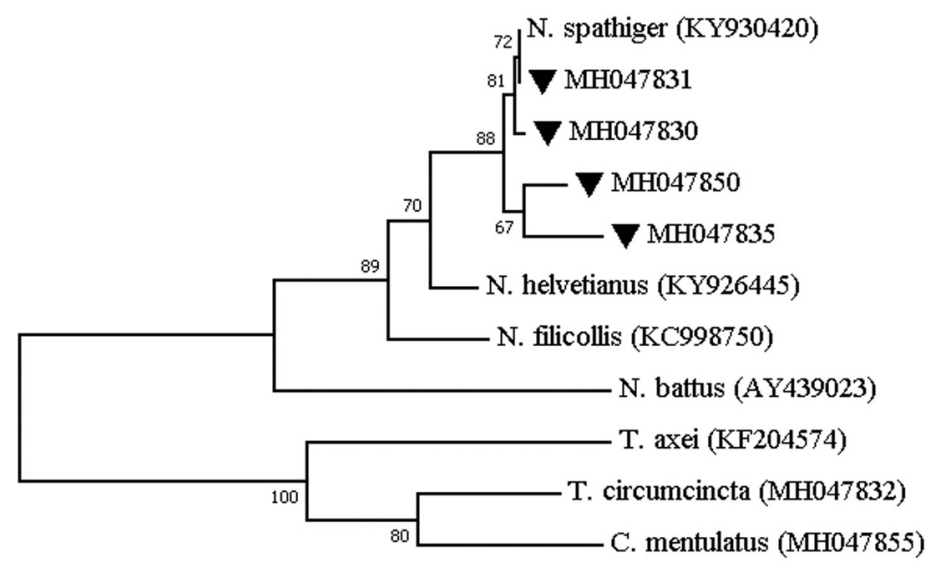

0.05

Figure 4. The phylogenetic relationships of Nematodirus spathiger based on ITS-2 sequences of the rDNA, using the Neighbor-Joining method with the Tamura 3-parameter method. The percentages of replicate trees in the bootstrap test (1000 replicates) are shown next to the branches. The tree is drawn to scale, with branch lengths in the same units as those of the evolutionary distances used to infer the phylogenetic tree. The analysis involved 11 nucleotide sequences (4 from antelopes, and 7 from Genbank). Evolutionary analyses were conducted in MEGA7. 
The phylogenetic analysis of the Trichostrongylus spp. sequences showed that they cluster well in the same clade with other species belonging to Trichostrongylus genus. Figure 5 provides information on genetic topology across these isolates.

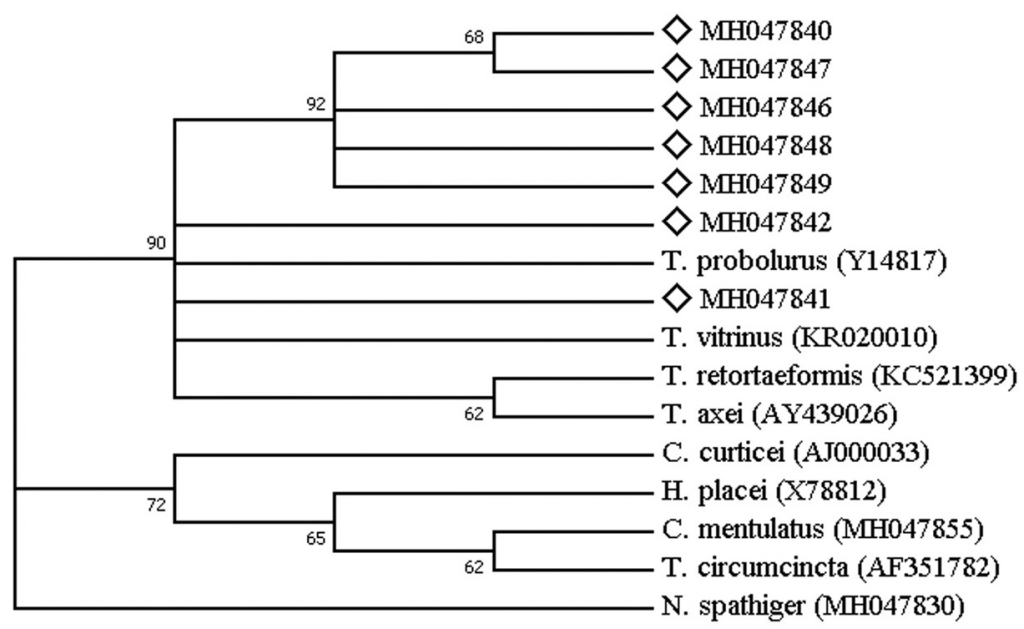

Figure 5. The phylogenetic relationships of Trichostrongylus spp. based on ITS-2 sequences of the rDNA, showing topology among species, using the Neighbor-Joining method with the Tamura 3-parameter method. The percentages of replicate trees in the bootstrap test (1000 replicates) are shown next to the branches. The analysis involved 16 nucleotide sequences (7 from antelopes, and 9 from Genbank). Evolutionary analyses were conducted in MEGA7.

\section{DISCUSSION}

The presented results clearly and accurately demonstrate through molecular tools, that all three antelope species are infected by $C$. mentulatus and N. spathiger, in addition to other Trichostrongylus spp. isolates detected in oryx and gazelles.

Geographically very widespread, C. mentulatus inhabits the abomasum and small intestine of ruminants. It has been reported in several species: in small domestic ruminants [27], in camelids [28] and in various wild ruminants [29]. In antelopes, this parasite causes abomasitis lesions and presents ostertagiosis-like symptoms: diarrhea, emaciation or even collapse in juveniles [30]. This study is in agreement with previous studies that mentioned $C$. mentulatus as a prevalent nematode species in African gazelles [13], in addax [31] and in oryx [32].

Unlike C. mentulatus, N. spathiger, which inhabits the small intestine of camelids and ruminants with a worldwide geographic distribution [33-35], does not usually cause clinical disease in adult ruminant hosts, but may cause dehydration syndrome in calves and lambs, attributable to larval migration-induced damage to the intestinal mucosa [36]. We can thus confirm by this study that N. spathiger is a nematode that is very common in Sub-Saharan antelopes, as previously reported in many studies [12,27]. 
Trichostrongylus species are ubiquitous among herbivores worldwide $[12,30,37,38]$. Generally, the adult parasites are encountered in the abomasum or in the small intestine of their hosts, in which they may cause weight loss, diarrhea and reduced growth rates [36]. In addition, some species of Trichostrongylus are related to many reported foodborne zoonosis cases [39,40].

Trichuris species, revealed by microscopy in the current study, inhabit the large intestine of their hosts and are also common parasites of many terrestrial mammals worldwide; the three species that may infect ruminants are T. ovis, T. discolor and T. globulosa, with light or asymptomatic infection [36].

Despite the scarcity of parasitological epidemiology studies in Sub-Saharan antelopes, the intensity and prevalence of parasites revealed in our study are globally comparable to those of previous studies of antelopes held under similar conditions. In fact, a study conducted in three African gazelle species (G. dorcas, G. cuvieri and G. damah mhorr) from Spain revealed close EPG values, for Trichuris spp. $(>100)$, for Nematodirus spp. $(<50)$ and for other Trichostrongylids $(>50)$, especially in dorcas gazelles [37]. In other studies in scimitar-horned oryx, for Nematodirus spp. $(=150)$ was also so closer to ours in which concern EPG value [41] or prevalence [30].

The relatively lower infection levels recorded in antelopes from SMNP, by analogy to domestic ruminants, may be explained by various factors. The most plausible explanation is related to spatial dimensions of host-parasite interactions, stating that host population density is positively correlated with their parasite burden [41,42]. The antelope population density within the park seems still to be low, which keeps the density of free-living forms of parasites (L3: third-stage infective larvae of nematodes) low in the pasture and avoids a continuous process of reinfection. These free-living forms of gastrointestinal nematodes require adequate conditions of moisture and temperature for their development from egg hatching to third larva molting $[43,44]$. The semiarid climate of the geographical area of the SMNP thus favors the host too, by reducing the infectivity potential of the free-living forms of parasites. Nevertheless, some of them can survive under extreme conditions, especially the larvae of $N$. spathiger, whose development takes place within eggs, where they are protected by the shell during the cold season until hatching in summer [45]. Other intrinsic factors, related to parasite developmental behavior, may explain the lower infection levels; $C$. mentulatus is characterized by its L3-L4 hypobiotic larvae, which, like those of Ostertagia spp., can delay their development and survive for several months in the mucosa of the abomasum before becoming adults [46]. The social behavior of the host can also explain such variation in the parasitic burden. The three studied African antelopes are recognized to be gregarious and to have a determined social organization, which makes parasite prevalence correlates positively with the size of the group in those African wild bovides, and territorial gazelle males are more likely to have higher parasites intensities than the rest of the herd [47]. This social behavior may explain the different levels of infections among the three populations of antelopes noted in our results. We 
have to take into consideration, also, that inbreeding in wildlife, especially in captivity and semi-captivity is a factor that makes animals more susceptible to parasitism [48].

In addition, food composition may directly or indirectly interact with gastrointestinal parasites. Some plants containing tannins, which are part of the ruminant diet, may help animals to improve their gastrointestinal immunological response or even have a direct negative effect by counteracting the growth of gastrointestinal nematodes [49]. At the SMNP, the flora is very diverse, and we find some tannin-rich species that are occasionally grazed by animals, such as Argania spinosa, Acacia gummifera, Retama monosperma, Ononis natrix, Atriplex halimus, etc., and thus could help antelopes to maintain low parasitic infection levels.

Based on the results of the current study and according to the host-parasite database [50], we recorded, for the first time, the prevalence of C. mentulatus and N. spathiger in the three antelope species in Morocco. These three antelopes can now be considered reservoirs for these parasites that should be taken into consideration for any further projected animal translocation or reintroduction operations.

\section{Acknowledgements}

We thank the SNMP administration and its staff, particularly Dr El Bekkay, for allowing this study to be carried out under optimal conditions.

\section{Authors' contributions}

AS and WO collected the fecal samples. AS carried out the laboratory analyses (Coprology and molecular biology). RM, FH, and WO participated in the design of the study, then prepared and critically revised the manuscript. All authors read and approved the final manuscript.

\section{Declaration of conflicting interests}

The author(s) declared no potential conflicts of interest with respect to the research, authorship, and/or publication of this article.

\section{REFERENCES}

1. Temple HJ, Cuttelod A: The Status and Distribution of Mediterranean Mammals. Gland, Switzerland and Cambridge, United Kingdom: IUCN; 2009, 32pp. ISBN 978-2-8317-11638

2. Aulagnier S, Bayed A, Cuzin F, Thévenot M: Mammifères du Maroc: extinctions et régressions au cours du XXème siècle. Trav Inst Sci Sér Gén 2015, 8: 53-67.

3. IUCN SSC Antelope Specialist Group: Addax Nasomaculatus. The IUCN Red List of Threatened Species. 2016: E.T512A50180603. [https://dx.doi.org/10.2305/IUCN. UK.2016-2.RLTS.T512A50180603.en] 
4. IUCN SSC Antelope Specialist Group: Oryx Dammah. The IUCN Red List of Threatened Species 2016: E.T15568A50191470. [https://dx.doi.org/10.2305/IUCN.UK.2016-2. RLTS.T15568A50191470.en]

5. UCN SSC Antelope Specialist Group: Gazella Dorcas. The IUCN Red List of Threatened Species 2017: E.T8969A50186334. [https://dx.doi.org/10.2305/IUCN.UK.2017-2.RLTS. T8969A50186334.en]

6. Müller HP, Heiner E: The Reintroduction of Herbivores to Souss Massa National Park, Morocco. In: The Biology, Husbandry and Conservation of Scimitar-horned oryx (Oryx dammah). Winchester, United Kingdom: Marwell Preservation Trust; 2004, 77-81. ISBN 0952139723

7. Ankouz M, Müller-Helmbrecht A, Beudels-Jamar RC, De Smet K: Agadir Declaration. Proceedings of the second regional seminar on the conservation and restoration of SaheloSaharan Antelopes 2003, 8: 3-9.

8. WOBESER G: Disease management strategies for wildlife. Rev Sci Tech 2002, 21(1):159178.

9. Artois M, Bengis R, Delahay RJ, Duchene MJ, Duff JP, Ferroglio E, Gortazar E, Hutchings MR, Kock RA, Leighton FA, Morner T, Smith GC, Delahay RJ, Smith GC, Hutchings MR: Wildlife disease surveillance and monitoring. In: Management of disease in wild mammals. Tokyo, Japan: Springer; 2009, 187-213. ISBN 09784431771333

10. Saidi A, Mimouni R, Hamadi F, Oubrou W: Cross-sectional study of Eimeria spp. infection in three antelope species (Addax nasomaculatus, Gazella dorcas and Oryx dammah) maintained in the Souss-Massa National Park (Morocco). Nat Conserv Res 2020, 5(Suppl.2): 77-82.

11. Saidi A, Mimouni R, Hamadi F, Oubrou W: Coprological survey of protostrongylid infections in antelopes from Souss-Massa National Park (Morocco). Helminthologia 2020, 57(4): 306-313.

12. Hoberg EP, Kocan AA, Rickard LG: Gastrointestinal strongyles in wild ruminants. In: Parasitic diseases of wild mammals. Ames, Iowa, Iowa State University Press; 2001, 193-227.

13. Ortiz J, De Ybáñez MR, Garijo MM, Goyena M, Espeso G, Abaigar T, Cano M: Abomasal and small intestinal nematodes from captive gazelles in Spain. J Helminthol 2001, 75(4): 363-365.

14. Botzler RG, Brown RN: Foundations of wildlife diseases. Oakland, California, Univ of California Press; 2014, 448pp. ISBN 9780520276093

15. Tompkins DM, Begon M: Parasites can regulate wildlife populations. Parasitol Today 1999, 15(8): 311-313.

16. Luzón M, Santiago-Moreno J, Meana A, Toledano-Díaz A, Pulido-Pastor A, GómezBrunet A, López-Sebastián A: Parasitism and horn quality in male Spanish ibex (Capra pyrenaica hispanica) from Andalucía based on coprological analysis and muscle biopsy. Span. J Agric Res 2008, 6(3): 353-361.

17. Marinković D, Aničić M, Özvegy J, Aleksić-Kovačević S: Epitheliogenesis Imperfecta in Dorcas Gazelle (Gazella dorcas) [abstract]. J Comp Pathol 2017, 156:138.

18. Nagy O, Tóthová C, Klein R, Chovanová F: The Electrophoretic Pattern of Serum Proteins in Sheep with Naturally Acquired Gastrointestinal Nematode Infections. Acta Vet 2020, 70(3): 316-328.

19. Hansen J, Perry BD: The Epidemiology, Diagnosis and Control of Helminth Parasites of Ruminants. FAO, Rome, Italy: ILRAD; 1994:129pp. ISBN 9290557031 [https://cgspace. cgiar.org/handle/10568/49809] 
20. Dryden MW, Payne PA, Ridley R, Smith V: Comparison of common fecal flotation techniques for the recovery of parasite eggs and oocysts. Vet Ther 2005, 6(1): 15-28.

21. Van Wyk JA, Mayhew E: Morphological identification of parasitic nematode infective larvae of small ruminants and cattle: A practical lab guide. Onderstepoort J Vet 2013, 80(1): 1-14.

22. Baermann G: Eine einfache methode zur auffindung von Ancylostomum (Nematoden) larven in erdproben. Geneeskd Tijdschr Ned Indie 1917, 57: 131-137.

23. Gasser RB, Chilton NB, Hoste H, Beveridge I: Rapid sequencing of rDNA from single worms and eggs of parasitic helminths. Nucleic Acids Res 1993, 21(10):2525-2526.

24. Johnson M, Zaretskaya I, Raytselis Y, Merezhuk Y, McGinnis S, Madden TL: NCBI BLAST: a better web interface. Nucleic Acids Res 2008, 36(2): 5-9.

25. Kumar S, Stecher G, Tamura K: MEGA7: molecular evolutionary genetics analysis version 7.0 for bigger datasets. Mol Biol Evol 2016, 33(7): 1870-1874.

26. Saitou N, Nei M: The neighbor-joining method: a new method for reconstructing phylogenetic trees. Mol Biol Evol 1987, 4(4): 406-425.

27. De Ybánez MRR, Garijo MM, Carpintero M, Martínez-Carrasco C, Ortiz JM: Camelostrongylus mentulatus in domestic goats from the Iberian Peninsula. J Helminthol 2003, 77(4): 371-372.

28. Chilton NB, Hoste H, Newton LA, Beveridge I, Gasser RB: Common secondary structures for the second internal transcribed spacer pre-rRNA of two subfamilies of trichostrongylid nematodes. Int J Parasitol 1998, 28(11): 1765-1773.

29. Goossens E, Dorny P, Boomker J, Vercammen F, Vercruysse J: A 12-month survey of the gastro-intestinal helminths of antelopes, gazelles and giraffids kept at two zoos in Belgium. Vet Parasitol 2005, 127(3-4): 303-312.

30. Wisser J, Tscherner W, Jantschke B: Infestation with Camelostrongylus mentulatus in dorcas gazelles (Gazella dorcas neglecta) caused lethal abomasitis. Erkrankungen der Zootiere: Verhandlungsbericht 2001, 40(81): 6.

31. SAID Y, Gharbi M, Mhadhbi M, Dhibi M, Lahmar S: Molecular identification of parasitic nematodes (Nematoda: Strongylida) in feces of wild ruminants from Tunisia. Parasitology 2018, 145(7): 901-911.

32. Pauling CD, Oller AR, Jackson V: Fecal parasite identification by microscopy and PCR in scimitar-horned oryx, Oryx dammah, managed at two sites. Int J Parasitol-Par 2016, 5(3): 312-320.

33. Audebert F, Cassone J, Kerboeuf D, Durette-Desset MC: Development of Nematodirus spathiger (Nematoda, Molineoidea) in the rabbit and comparison with other Nematodirus spp. parasites of ruminants. Parasitol Res 2004, 94(2): 112-117.

34. Morgan ER., Shaikenov B, Torgerson PR, Medley GF, Milner-Gulland EJ: Helminths of saiga antelope in Kazakhstan: implications for conservation and livestock production. J Wildl Dis 2005, 41(1): 149-162.

35. Mohammed OB, Omer SA, Sandouka MA: The efficacy of Ivermectin and Levamisole against natural Nematodirus spathiger infection in the Arabian sand gazelle (Gazella subgutturosa marica) and the Arabian mountain gazelle (Gazella gazella) in Saudi Arabia. Vet Parasitol 2007, 150(1-2): 170-173.

36. Taylor MA, Coop RL, Wall R: Veterinary parasitology. 4th ed. Chichester, West Sussex, United Kingdom: John Wiley \& Sons; 2016, 1032pp. ISBN: 9780470671627

37. Ortiz J, De Ybáñez RR, Abaigar T, Goyena M, Garijo M, Espeso G, Cano M: Output of gastrointestinal nematode eggs in the feces of captive gazelles (Gazella dama mborr, Gazella 
cuvieri and Gazella dorcas neglecta) in a semiarid region of southeastern Spain. J Zoo Wildlife Med 2006, 37(3): 249-254.

38. Fagiolini M, Lia RP, Laricchiuta P, Cavicchio P, Mannella R, Cafarchia C, Otranto D, Finotello R, Perrucci S: Gastrointestinal parasites in mammals of two Italian zoological gardens. J Zoo Wildlife Med 2010, 41(4): 662-670.

39. Pestechian N, Kalani H, Faridnia R, Yousefi HA: Zoonotic gastrointestinal nematodes (Trichostrongylidae) from sheep and goat in Isfahan, Iran. Acta Sci Vet 2014, 42(1): 1-6.

40. Phosuk I, Intapan PM, Sanpool O, Janwan P, Thanchomnang T, Sawanyawisuth K, Morakote N, Maleewong W: Molecular evidence of Trichostrongylus colubriformis and Trichostrongylus axei infections in humans from Thailand and Lao PDR. Am J Trop Med Hyg 2013, 89(2): 376379.

41. Arneberg P, Skorping A, Grenfell B, Read AF: Host densities as determinants of abundance in parasite communities. Proceedings of the Royal Society of London. Series B: Biological Sciences 1998, 265(1403): 1283-1289.

42. Holt R, Boulinier T: Ecosystems and parasitism: the spatial dimension. In: Parasitism and ecosystems. Oxford, United Kingdom: Oxford University Press; 2005, 68-84. ISBN 9780198529873

43. O'connor, LJ, Walkden-Brown SW, Kahn LP: Ecology of the free-living stages of major trichostrongylid parasites of sheep. Vet Parasitol 2006, 142(1-2): 1-15.

44. Khadijah S, Kahn LP, Walkden-Brown SW, Bailey JN, Bowers SF: Soil moisture modulates the effects of the timing and amount of rainfall on faecal moisture and development of Haemonchus contortus and Trichostrongylus colubriformis to infective third stage larvae. Vet Parasitol 2013, 196(3-4): 347-357.

45. Gibson TE, Everett G: Ecology of the free-living stages of Nematodirus spathiger. Res Vet Sci 1982, 32(1): 35-38.

46. Beveridge I, Barker IK, Rickard MD, Burton JD: Experimental infection of sheep with Camelostrongylus mentulatus and associated gastritis. Aust Vet J 1974, 50(1): 36-37.

47. Ezenwa VO: Host social behavior and parasitic infection: a multifactorial approach. Behav Ecol 2004, 15(3): 446-454.

48. Cassinello J, Gomendio M, Roldan ERS: Relationship between coefficient of inbreeding and parasite burden in endangered gazelles. Conserv. Biol. 2001;15(4):1171-1174. DOI: https://doi.org/10.1046/j.1523-1739.2001.0150041171.x

49. Hoste H, Jackson F, Athanasiadou S, Thamsborg SM, Hoskin SO: The effects of tanninrich plants on parasitic nematodes in ruminants. Trends Parasitol 2006, 22(6): 253-261.

50. Gibson DI, Bray RA, Harris EA: Host-parasite database of the natural history museum. London, 2005. [https://www.nhm.ac.uk/research-curation/scientific-resources/ taxonomy-systematics/host-parasites/] 


\title{
ISPITIVANJE INFEKCIJE GASTROINTESTINALNIM NEMATODAMA KOD ANTILOPA U MAROKU
}

\author{
SAIDI Aissa, MIMOUNI Rachida, HAMADI Fatima, OUBROU Widade
}

U studiji je sprovedeno ispitivanje parazitološkog statusa intestinalnog trakta kod tri ugrožene vrste subsaharske antilope (Addax nasomaculatus, Oryx dammah, Gaz̧ella dorcas) koje su se nalazile u Souss-Massa nacionalnom parku u Maroku. Da bi se ispitala prevalencija i intenzitet infestacije parazitima kod životinja, ukupno je ispitano 254 uzoraka fecesa (80 uzoraka iz addax populacije, 81 uzoraka iz orix populacije i 93 uzoraka iz dorcas populacije) pri čemu su rezultati prikazivani kao srednja vrednost EPG (jajašca parazita po gramu fecesa). Korišćene su mikroskopske metode (Flotacija i McMaster) kao i molekularna identifikacija parazita upotrebom PCR testa i sekvencioniranjem rDNK (ITS-2).

Rezultati prevalence Nematodirus spp kod addax, oryx i dorcas gazela bili su: 43,7\%, 2,4\% odnosno 61,3\%; za Trichuris spp vrste $21,2 \%, 12,3 \%$ i 16,3\%, a za strongilidne vrste koje nisu mogle da se determinišu: 36,2\%, 39,5\% i 53,7\%.

Srednje EPG vrednosti za parazite kod adax, oryx i dorcas gazele bili su za Nematodirus spp vrste 8,9, 2,4 i 61,3; za Trichuris 4,3, 2,4 i 4,8 a za na strongilidne vrste koje nisu mogle da se determinišu, 18,1, 16,6 odnosno 50,1. Rezultati sekvencioniranja ITS-2 regiona rDNK izolovanih parazita omogućio je identifikaciju Camelostrongylus mentulatus i Nematodirus spathinger u navedene tri vrste antilopa. Može da se zaključi da su infestacije parazitima kod ove tri vrste antilopa na podnošljivom nivou pri čemu je po prvi put dijagnostikovana infestacija antilopa u Maroku sa Camelostrongylus mentulatus i Nematodirus spathinger. 